\title{
Recent variations and regional relationships in Northern Hemisphere snow cover
}

\author{
David A. Robinson, Allan Frei, \\ Department of Geography, Rutgers University, New Brunswick, NJ 08903, U.S.A. \\ Mark C. Serreze \\ Division of Cryospheric and Polar Processes, Cooperative Institule for Research in Environmental Sciences, University of Colorado, \\ Boulder, CO 80309, U.S.A.
}

\begin{abstract}
An analysis of snow-cover variability over Northern Hemisphere land masses reveals a continuation of the subnormal coverage that began in the late 1980 s (relative to the 1972- present interval). While the 1994 snow year (September 1993-August 1994) exhibited a return to near-normal hemispheric extent, only three months during this period had above-normal coverage. Only 11 of the past 88 months (through October 1994) have been above the norm. Deficits have been most common in spring, over both the Eurasian and North American continents. This is a hemisphere-wide situation; positive correlations are identified between hemispheric and regional snow extents in spring, as well as in fall and winter. A number of significant associations are also recognized between regions during these three seasons; however, it is uncommon to see more than $50 \%$ of the variance in one region explained by another. These correlations are most common between adjacent regions, but some are found between regions on different continents. Only in spring are significant positive relationships between non-adjacent regions on the same continent observed.
\end{abstract}

\section{INTRODUCTION}

Snow cover over the Northern Hemisphere represents an important and highly variable component of the global climate system. On average, Northern Hemisphere snow cover peaks in winter at about $46 \times 10^{6} \mathrm{~km}^{2}$, covering approximately $46 \%$ of the land surface (Robinson and others, 1993). Coverage decreases to about $4 \times 10^{6} \mathrm{~km}^{2}$ in August, but exhibits large variability in all months. The extent of snow cover is influenced by various factors, including the location of the jet stream and polar front, the associated frequency and intensity of winter storms, and variations in temperature, solar radiation and cloudiness. The presence of snow can influence climatic conditions both near the surface and through most of the troposphere. It has been observed frequently that snow cover suppresses low-level air temperatures over timescales of days to months (e.g. Namias, 1962; Dewey, 1977), through the effects of both increased albedo and the latent heat of melt. Snow can influence atmospheric circulation through its effects on diabatic heating, which will be determined by the extent, depth and location of the snow-covered surface.

Recognition of the climatic significance of snow has fostered studies regarding its hemispheric distribution and variability, and potential feed-backs within the atmosphere associated with snow cover. Such studies utilize station records (e.g. Pfister, 1985; Robinson and Hughes, 1991), satellite-derived archives (e.g. Robinson and Dewey, 1990; Iwasaki, 1991; Gutzler and Rosen, 1992; Masuda and others, 1993) or both (Karl and others, 1993; Leathers and Robinson, 1993). These studies have tended to be on local or continental levels; less attention has been paid to the regional scale. Here, we will document and discuss snow-cover variability over Northern Hemisphere land masses, concentrating on the distribution and temporal variations of snow cover within and between regions. This is a critical step towards better understanding relationships between atmospheric variability and fluctuations in snow cover.

\section{DATA AND METHODOLOGY}

\section{Snow charts}

Weekly snow charts produced by the U.S. National Oceanic and Atmospheric Administration (NOAA) are the primary source of information for this investigation. These charts depict boundaries between snow-covered and snow-free land surfaces, and are produced from visual interpretation of photographic copies of visible-band satellite imagery. Charts show snow boundaries on the last day that the surface in a given region is observed. 
Since cloud cover can mask the surface, this is often not the last day of the chart week. On average, charts tend to represent the fifth day of a chart week. Charts are digitized on a weekly basis to the U.S. National Meteorological Center limited-area fine mesh (LFM) grid (for further details on NOAA charts see Matson and others, 1986; Robinson, 1993). While NOAA charts have been produced since 1966, early charts tended to underestimate snow extent, particularly during autumn. Charting accuracy improved considerably in 1972, when NOAA very high resolution radiometer (VHRR) and Advanced VHRR data began to be used. Data since 1972 are considered to be of a high enough quality for use in climate studies (Wiesnet and others, 1987).

\section{Monthly snow cover}

Monthly means of snow-cover area are calculated using a routine described fully in Robinson (1993). Briefly, the Rutgers routine weekly calculates areas from the digitized snow files and weights them according to the number of days of a chart week falling in the given month. A chart week is considered to center on the fifth day of the published chart week. Prior to the calculations, the digital files are standardized to a common land mask, which includes those and only those LFM cells at least half covered by land. This corrects an inconsistency in the original NOAA files.

\section{Regions}

Criteria used in the selection of regions for this study (Fig. 1) include climatic similarity and size. The former aligns closely with physiography and latitude, while the latter includes areas large enough to contain a number of LFM cells (varying from 16000 to $42000 \mathrm{~km}^{2}$ ), yet small enough to maintain a considerable degree of internal homogeneity. Regions are small relative to major atmospheric features, such as stationary waves. The 21 regions decided upon range from $10^{6}$ to $4 \times 10^{6} \mathrm{~km}^{2}$ in size; 9 are in North America and 12 in Eurasia.

\section{NORTHERN HEMISPHERE SNOW COVER}

Mean (and median) annual Northern Hemisphere snow cover is $25.3 \times 10^{6} \mathrm{~km}^{2}, 14.7 \times 10^{6} \mathrm{~km}^{2}$ lying over Eurasia and $10.6 \times 10^{6} \mathrm{~km}^{2}$ over North America. The hemispheric and North American values include the Greenland land mass (approx. $2 \times 10^{6} \mathrm{~km}^{2}$ ). The variability of snow cover over the Northern Hemisphere between January 1972 and December 1993 is expressed in Figure 2 as monthly anomalies and 12 month running means. Monthly anomalies of greater than $4 \times 10^{6} \mathrm{~km}^{2}$ have occasionally been observed during the past 22 years, although they are generally less than $2 \times 10^{6} \mathrm{~km}^{2}$. Extended periods of above-average snow extent occurred in the early and late 1970s and the mid-1980s. Somewhat below-normal coverage was observed in the mid-1970s and early 1980s. However, it is since the late 1980s that the longest interval of subnormal snow cover in the past two decades has been observed. While the 1994 snow year (September 1993-August 1994) exhibited a return to

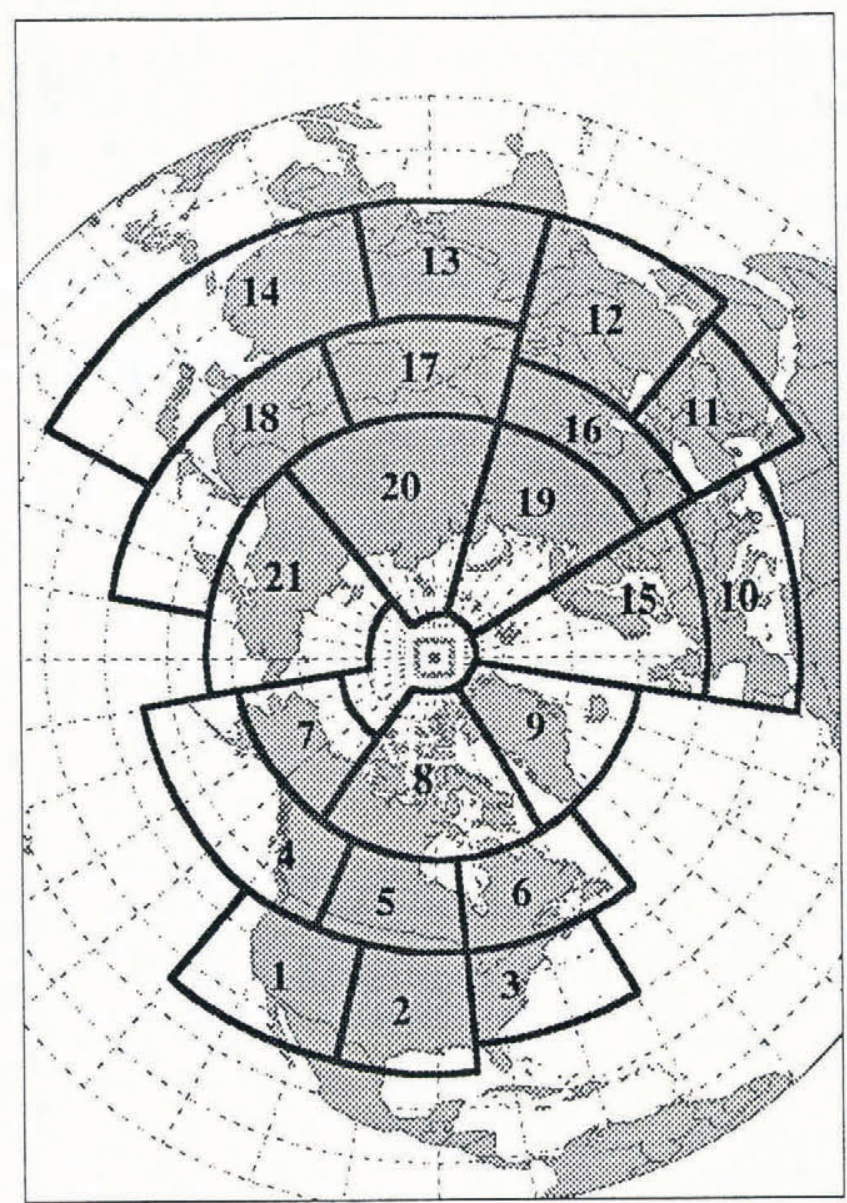

Fig. 1. Regions $(R)$ analyzed in this study. Only land situated within these regions is included in the study.

near-normal hemispheric extent, only three months during this period had above-normal coverage. Only 11 of the past 88 months (through October 1994) have been above the norm. Negative departures of snow cover over the past 6 years have been most pronounced in spring. Summer coverage has also been below normal in recent

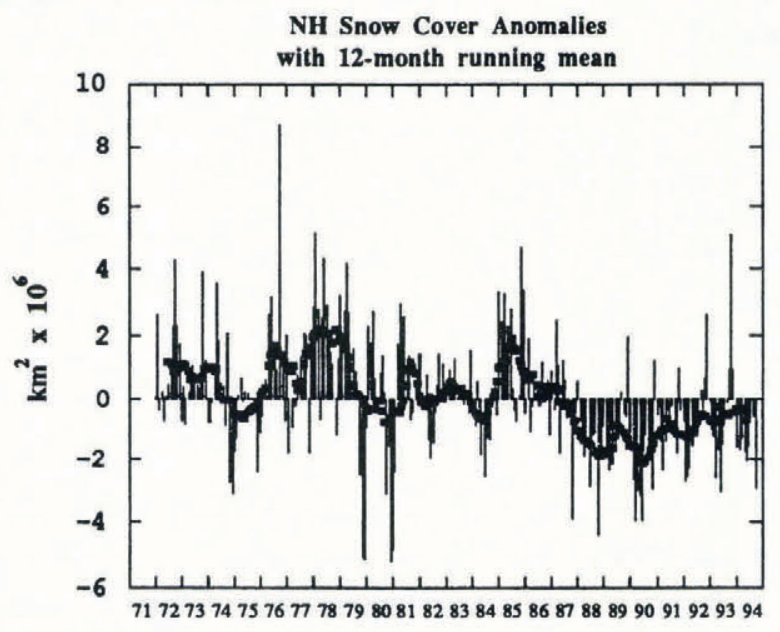

Fig. 2. Anomalies of monthly snow-cover extent over Northern Hemisphere lands (including Greenland), January 1972-October 1994. Also shown are 12 month running anomalies of hemispheric snow extent, plotted on the seventh month of a given interval. 
years. Winter has been the most stable season throughout the satellite era, with fall exhibiting most variability from one year to the next.

\section{REGIONAL SNOW COVER}

Looking next at regional characteristics of seasonal snow cover across Northern Hemisphere land masses, representative months (November, January, April) for the three primary snow seasons are examined. Box and whisker plots showing the extent of cover within each region from 1972 to the present are presented in Figure 3. For November, the highest variability on a year-toyear basis (Fig. 3a) is seen in the more northerly midlatitude regions (R4-6, R 15-18) and northeastern Europe (R19). In these regions the interquartile range commonly exceeds $20 \%$. The full range of coverage in November is as high as $60 \%$ (R5). High variability in January snow cover (Fig. 3b) is found on both sides of the Atlantic (R3, R10, R15). The two other midlatitude regions in North America (R1, R2) exhibit the next greatest variability. In April, the regions with the largest year-to-year variability are in the more northerly middle latitudes (R4-6, R 15-18). However, these differences are not as pronounced as in November. Some variability in April coverage is observed in northeastern Europe and north central Eurasia (R1920), while the rest of the regions in Eurasia (R21) and North America (R7-9) remain snow-covered, as they do in the other two study months.

Time series from four selected regions for each study month (Fig. 4) illustrate large year-to-year differences in snow coverage in some regions (e.g. R 5 in November, R3 in January, R5 in April) as compared to others (e.g. R6 in November, R1 in January, R6 in April). In April, the region from north of the Black Sea eastward into the
Asian steppe (R16) and the three North American regions close to and north of the U.S.-Canadian border (R4-6) show relatively low spring-snow extents in recent years. The reduction is more pronounced when viewed collectively over the hemisphere for the entire spring, where the last seven springs each had less snow cover than the previous sixteen.

\section{HEMISPHERIC-REGIONAL COMPARISONS}

Spearman rank correlations are computed between regional (dependent-variable) and hemispheric (independent-variable) time series to identify regions that are most representative of year-to-year variations in hemispheric snow cover. In this non-parametric technique, correlations are computed on the rankings. Table 1 presents the results for those regions having on average $10-90 \%$ snow coverage in a particular study month. A positive correlation between individual regions and overall hemispheric cover is seen in each season. In no case is there a negative correlation i.e. inverse relationship) significant at the $\geq 95 \%$ level. In November, 9 of the 11 regions have a correlation with hemispheric cover significant at the $\geq 95 \%$ level ( six of these $\geq 99 \%$ ). The strongest correlation with hemispheric cover in November is in the Asian steppe region (R16), where over half of the variance is explained. Fairly strong relationships are also observed between hemispheric cover and that over the central U.S.A. (R2) in January. In this month 7 of the 10 regions have significant associations with the hemispheric cover exceeding $95 \%$ (four of these $\geq 99 \%$ ). The number of significant correlations (9 of 11 regions $\geq 95 \%$ level) remains high in April, and five of these are significant at the $\geq 99 \%$ level, although none explains more than about $40 \%$ of the variance. Thus, many regions have contributed to the lower spring coverage in recent years.
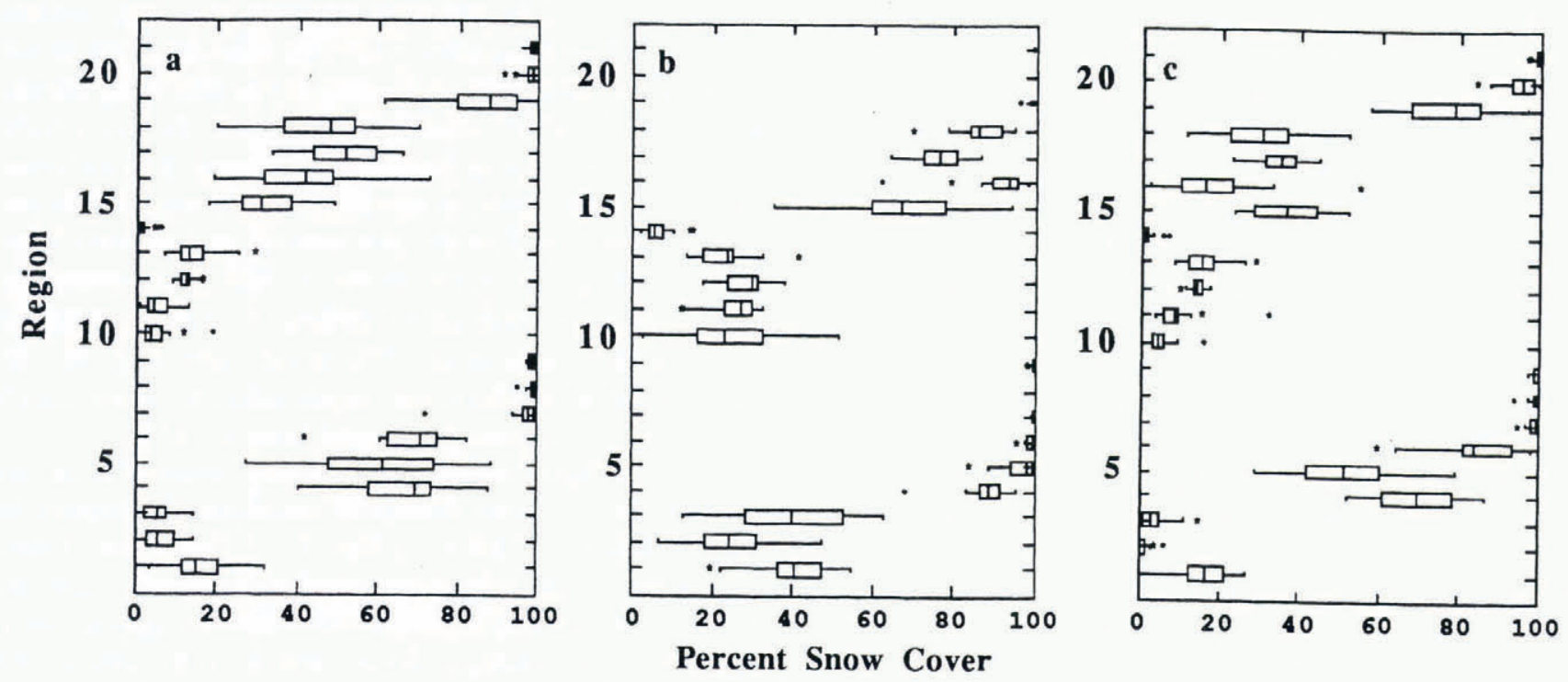

Fig. 3. Snow cover over Northern Hemisphere regions ( $c$. Fig. 1) in (a) November over the past 22 years, (b) January over the past 23 years, (c) April over the past 23 years. The median percentage coverage is the vertical line within the regional boxes, and the interquartile range (ICR) is between the top and bottom of the box. Whiskers show the extreme values between +1 and $+1.5 \times I C R$ and -1 and $-1.5 \times I C R$, and asterisks show values in individual years falling outside of the \pm 1.5 ranges. 
a. NOVEMBER

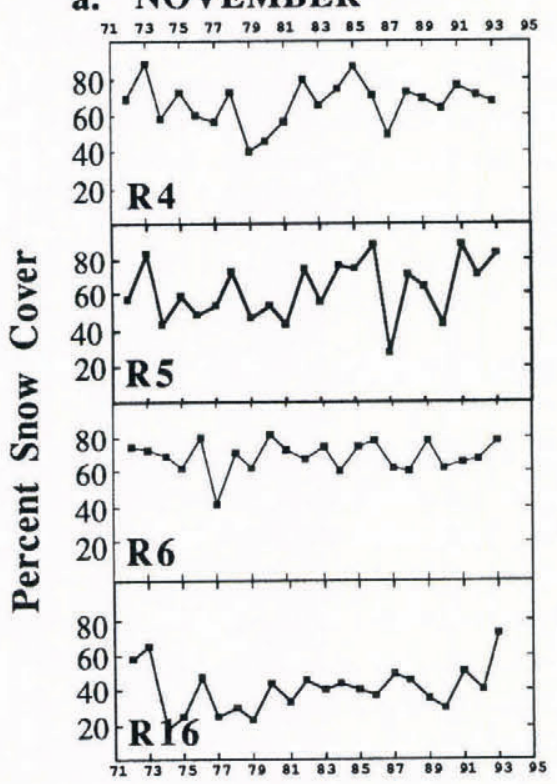

b. JANUARY

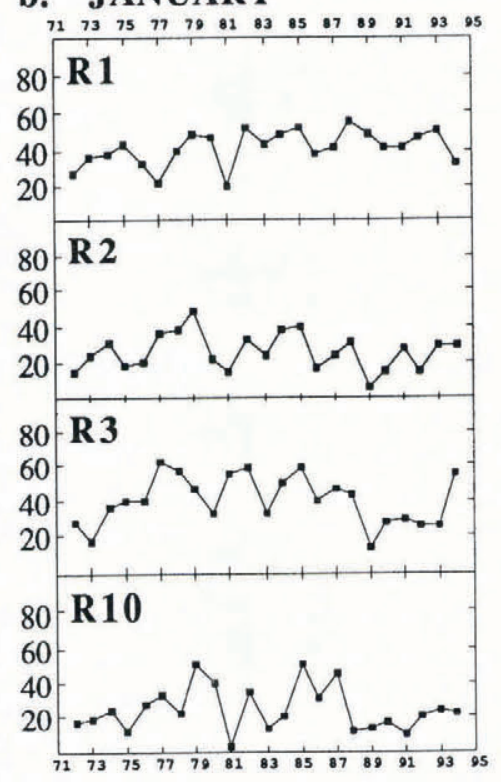

c. APRIL

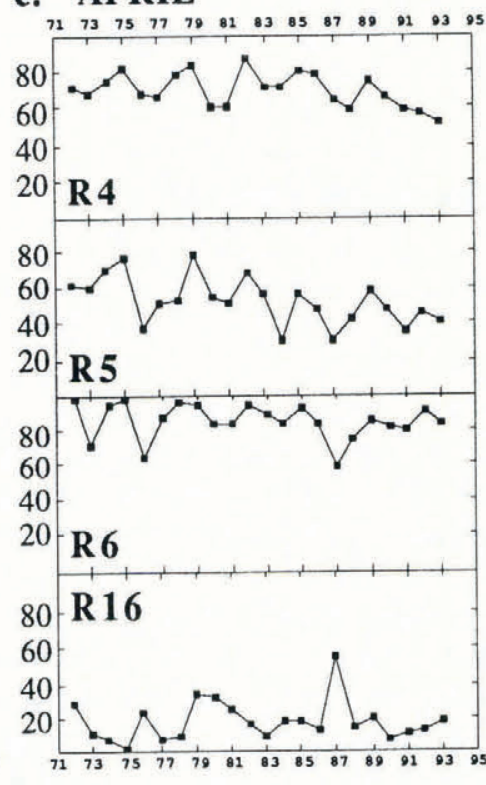

Year

Fig. 4. Time series showing the percentage snow coverage within selected regions (cf. Fig. 1) in (a). November, (b) January, and (c) April.

\section{INTER-REGIONAL GOMPARISONS}

Inter-regional relationships are also explored, again using a Spearman analysis and concentrating on the regions with 10-90\% snow coverage. Results for all qualifying regions are shown in Table 2 and summarized in Table 3. A number of significant positive correlations are seen;

Table 1. Correlations between hemispheric and regional snow cover for those regions ( $\mathrm{R}$ ) averaging $\geq 10 \%$ and $\leq 90 \%$ snow cover in a selected month over the past 22 (November, April) or 23 years (January) (cells are left blank when criteria for a given month are not met). Spearman correlation coefficients $\geq 0.35$ are significant at the $\geq 95 \%$ level and those $\geq 0.50$ are significant at the $\geq 99 \%$ level

\begin{tabular}{lccc}
\hline$R$ & November & January & April \\
\hline 1 & & & \\
2 & 0.36 & 0.36 & 0.54 \\
3 & & 0.68 & \\
4 & & 0.39 & \\
5 & 0.50 & & 0.43 \\
6 & 0.58 & & 0.52 \\
10 & 0.50 & & 0.26 \\
11 & & 0.51 & \\
12 & & 0.24 & \\
13 & 0.47 & 0.56 & 0.24 \\
15 & 0.28 & 0.28 & 0.51 \\
16 & 0.42 & 0.64 & 0.64 \\
17 & 0.74 & & 0.39 \\
18 & 0.67 & 0.47 & 0.49 \\
19 & 0.60 & 0.14 & 0.57 \\
& 0.57 & & 0.41 \\
\hline
\end{tabular}

however, it is uncommon to see more than $50 \%$ of the variance in one region explained by another. No significant negative correlations are observed. Despite 110 inter-regional correlations being non-significant, it is interesting to note that 78 of these are positive and only 32 negative.

Significant positive correlations are most common between adjacent regions, but some are found between regions on different continents (Table 3). Only in April are significant positive relationships between non-adjacent regions on the same continent observed. Figure 4 provides examples of some of these relationships over the past several decades. In November (Fig. 4a) there is a positive correlation between R4 and R5 over the high middle latitudes of North America, while R6, adjacent to R5, is not significantly correlated with either R4 or R5. A significant relationship $(\geq 95 \%$ level $)$ is observed in November between R5 in central North America and R16 covering the region from north of the Black Sea eastward into the Asian steppe. In January the central and eastern midlatitude regions of North America (R2-3) are positively correlated, while there is no significant correlation between either of these regions and Rl to the west (Fig. 4b). In January, R2 and R3 are correlated with the region which encompasses southern and central Europe (R10).

The strongest correlations of any regions occur in April over the more northerly mid-latitude regions of North America (R4-6) (Fig. 4c). These are being examined further, using principal components analysis. Preliminary results indicate a coherent spring zone approximately $500 \mathrm{~km}$ wide, which runs along the Canadian-U.S. border between Maine and southern Saskatchewan, then turns northwestward into east central Alberta. This zone had excessive April snow cover in 1975, 1979 and 1982, and low coverage in 1988-94. Unlike in November, there is no significant relationship between R5 and R16. 
Table 2. Correlations of snow-cover extent between regions ( $\mathrm{R}$ ) for those regions averaging $\geq 10 \%$ and $\leq 90 \%$ snow cover in November, January and April over the past 22 (November, April) or 23 years (January). Spearman correlation coefficients $\geq 0.35$ are significant at the $\geq 95 \%$ level and those $\geq 0.50$ are significant at the $\geq 99 \%$ level

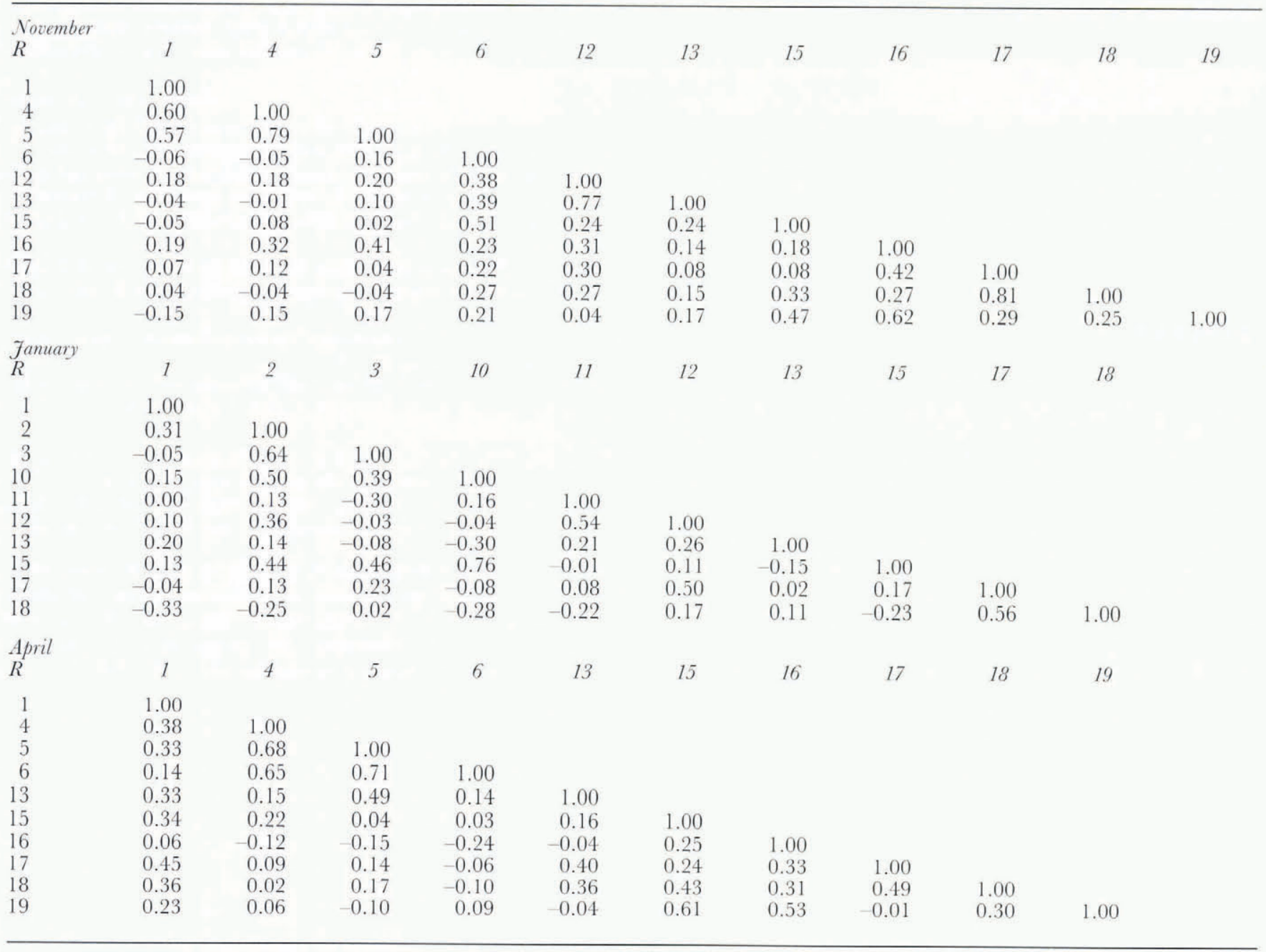

\section{DISCUSSION AND CONGLUSIONS}

Since the late 1980s, the extent of snow cover over Northern Hemisphere lands has been below average. However, given the relatively short satellite-data record, it is difficult to fully understand the meaning of the recent negative snow anomalies. It is certainly premature to ascribe the recent deficits to global warming. However, it is interesting to note that the extent of snow cover appears to be inversely related to hemispheric surface air temperature (Robinson and Dewey, 1990), and, particularly in spring, feed-backs associated with the extent of the snowpack may be strongly influencing temperature (Groisman and others, 1994).

There are, no doubt, a number of factors contributing to the variable distribution of hemispheric snow cover from one year to the next. On the one hand, relationships between hemispheric and regional snow extents suggest broad hemispheric forcings, perhaps related to the dimensions of the polar vortex. Conversely, differences across the continents suggest forcings associated with regional variations in the position, amplitude and strength of the jet stream and polar front. Intercontinental similarities in snow variability may be associated with climatic teleconnections. In the future we intend to expand this investigation to include sea ice and to incorporate fuller and more detailed temporal and higher spatial resolutions. Lagged correlations will also be studied, and investigations of possible atmospheric

Table 3. Number of inter-regional correlations falling under specified categories for those regions averaging $\geq 10 \%$ to $\leq 90 \%$ snow cover in a selected month. See Table 2 for specific correlations and text for definition of categories

November January April

$\begin{array}{lrrr}\geq 99 \% & 7 & 6 & 5 \\ \geq 95 \% \text { to <99\% positive } & 5 & 4 & 8 \\ \text { non-significant positive } & 35 & 20 & 23 \\ \text { non-significant negative } & 8 & 15 & 9 \\ \geq 95 \% \text { : adjacent regions } & 8 & 5 & 6 \\ \geq 95 \% \text { : non-adjacent regions, } & & & \\ \quad \text { same continent } & 0 & 0 & 3 \\ \geq 95 \% \text { : other continent } & 4 & 5 & 4\end{array}$


forcings associated with year-to-year snow-cover variability and inter-regional associations will be conducted.

\section{AGKNOWLEDGEMENTS}

Thanks to D. Garrett at the NOAA Climate Analysis Center for providing continuous updates of the raw digitized NOAA snow-chart data, and J. Wright for running the Rutgers routine on these files. This work is supported by NSF grants ATM-9314721, ATM-9315351 and SBR-9320786, and NASA grant NAGW-3568.

\section{REFERENCES}

Dewey, K.F. 1977. Daily maximum and minimum temperature forecasts and the influence of snow cover. Mon. Weather Rev., 105. $1594-1597$.

Groisman, P. Ya., T. R. Karl and R. W. Knight. 1994. Observed impact of snow cover on the heat balance and the rise of continental spring temperatures. Science, $263(5144), 198200$.

Gutzler, D.S. and R.D. Rosen. 1992. Interannual variability of wintertime snow cover across the Northern Hemisphere. J. Climate, 5 12) 1441-1447.

Iwasaki, T. 1991. Year-to-year variation of snow cover area in the Northern Hemisphere, f. Meteorol. Soc. Jph, 69 2), $209-217$.

Karl, T. R.. P. Ya. Groisman, R. W. Knight and R. R. Heim, Jr. 1993. Recent variations of snow cover and snowfall in North America and their relation to precipitation and temperature variations, 7 . Climate, 6(7), 1327-1344.

Leathers, D.J. and D.A. Robinson. 1993. The association between extremes in North American snow cover extent and United States temperatures. 7 . Climate, 6 (7), 1345-1355.

Masuda, K., Y. Morinaga, A. Numaguti and A. Abe-Ouchi. 1993. The annual cycle of snow cover extent over the Northern Hemisphere as revealed by NOAA/NESDIS satellite data. Tokyo Metropolitan Universily. Geogr. Rep. 28, 113-132.

Matson, M., C.F. Ropelewski and M.S. Varnadore. 1986. An atlas of satellite-derived Northern Hemisphere snow cover frequency. Washington, DC, National Oceanographic and Atmospheric Administration.

Namias, J. 1962. Influences of abnormal surface heat sources and sinks on atmospheric behavior. In Proceedings. International Symposium on Numerical Weather Prediction, 1960. Meteorological Socicty of Japan, 615-627.

Pfister, C. 1985. Snow cover, snow lines and glaciers in central Europe since the 16th century. In The climatic scene. George Allen and Unwin, 154174.

Robinson, D.A. 1993. Monitoring Northern Hemisphere snow cover. Glaciol. Data Rep. GD25, 1-25.

Robinson, D. A. and K. F. Dewey, 1990. Recent secular variations in the extent of Northern Hemisphere snow cover. Geophys. Res. Lelt., 17 (10). 1557-1560.

Robinson, D. A. and MG. Hughes. 1991. Snow cover variability on the northern and central Great Plains. Great Plains Res., 1, 93-113.

Robinson, D.A., K.F. Dewey and R. Heim, Jr. 1993. Northern Hemispheric snow cover: an update. Bull. Am. Meteorol. Soc., 74, 1689 1696.

Wiesnet, D. R., C. F. Ropelewski, G. J. Kukla and D. A. Robinson. 1987. A discussion of the accuracy of NOAA satellite-derived global seasonal snow cover measurements. International Association of Hydrological Sciences Publication 166 (Symposium at Vancouver 1987 - Large-Scale Effects of Seasonal Snow Cover), 291-304. 